Acta vet. scand. $1977,18,349-360$.

From the State Veterinary Institute for Virus Research, Lindholm, Kalvehave, Denmark.

\title{
SAPONIN ADJUVANTS \\ IV. EVALUATION OF THE ADJUVANT QUIL A IN THE VACCINATION OF CATTLE AGAINST FOOT-AND-MOUTH DISEASE
}

By

K. Dalsgaard, Merethe H. Jensen and K. J. Sфrensen

\begin{abstract}
DALSGAARD, K., MERETHE H. JENSEN and K. J. SØRENSEN: Saponin adjuvants. IV. Evaluation of the adjuvant Quil $A$ in the vaccination of cattle against foot-and-mouth disease. Acta vet. scand. 1977, 18, 349-360. - The saponin adjuvant Quil A has been investigated in the vaccination of cattle against foot-and-mouth disease. Using a Frenkel type vaccine a dose-response relationship has been established between Quil A and neutralizing antibody titres. Ten $\mathrm{ml}$ of vaccine was combined with $0,50,200,800$, and $3200 \mu \mathrm{g}$ of Quil A. The combinations were each injected into 4 animals. The local reaction on the site of injection produced by injection of the vaccine alone and in combination with different doses of Quil A has been estimated. On this basis a therapeutical dose at $1 \mathrm{mg}$ of Quil $\mathrm{A}$ has been estimated to combine maximum adjuvant effect with a minimum of adverse reactions. This dose has been tested in the vaccination of cattle with FMD vaccines derived from BHK suspension cell virus of type $O$ and A respectively. The vaccines were tested in $10 \mathrm{ml}$ and $5 \mathrm{ml}$ doses with or without Quil A, and each in 4 animals. It is concluded that Quil A is a valuable adjuvant for use in the induction of neutralizing antibodies against foot-and-mouth disease in cattle.
\end{abstract}

adjuvant; FMD; saponin; vaccines; neutralizing antibodies; Quil A.

The adjuvant effect of certain commercially available saponins in the vaccination against foot-and-mouth disease (FMD) is well established (Espinet 1951, Hyslop \& Morrow 1969, Wehmeyer 1969, Anderson et al. 1971, Charlier et al. 1973). However, since saponins are extracted from natural plant material, the adjuvant effect is not predictable. Most commercial samples are mixtures of at least 5 different substances (Dalsgaard 1970). The parenteral application of such mixtures is from an immunological and medical point of view highly undesirable. Hence 
efforts have been made to obtain a well defined product. In a previous publication (Dalsgaard 1974) it was demonstrated that a virtually pure adjuvant active substance, Quil A, could be isolated from the cortex of Quillaja saponaria Molina. The purpose of the present report has been 1) to estimate the dose-response relationship of Quil $A$ in the vaccination of cattle against FMD, 2) to estimate the local reaction produced by Quil $A$ and to establish a therapeutic dose, 3) to investigate the practical use of Quil A when added to FMD vaccines from BHK suspension cell virus.

\section{MATERIALS AND METHODS}

\section{Animals}

A total of 52 heads of cattle were used. The animals were of the Danish breed SDM, approx. 2 years old, weighing about $500 \mathrm{~kg}$.

\section{Vaccines}

A stock vaccine (non-concentrated) of serotype $\mathrm{C}$ virus derived from surviving bovine tongue epithelium (Frenkel type) containing aluminium hydroxide $\left(0.65 \%\right.$ as $\left.\mathrm{Al}_{2} \mathrm{O}_{3}\right)$ and inactivated by $0.05 \%$ formaldehyde $\left(48 \mathrm{hrs} ., 26^{\circ} \mathrm{C}\right)$ was used for the dose-response experiment (Frenkel 1950). Two stock vaccines of serotype $O$ and $A$ respectively, derived from $B H K$ suspension cell virus prepared as indicated above, were used for the estimation of adjuvant activity of Quil A in therapeutic doses.

\section{Quil A}

The Quil A was prepared as described in a previous publication (Dalsgaard 1974). Quil A was added to the vaccine as a $10 \%$ solution in distilled water. After the addition the vaccines were equilibrated by gentle stirring for $30 \mathrm{~min}$. at room temperature.

\section{Adjuvant activity}

Neutralizing antibodies were assayed by titration in tubes of primary calf kidney cells, and the neutralizing titres (ND50) were calculated according to the method of Kärber (1931). Serial 2-fold dilutions with 4 tubes per dilution were used. In the doseresponse experiment $10 \mathrm{ml}$ of the Frenkel type vaccine was injected subcutaneously into 5 groups of 4 animals. The 5 groups 
recieved 0, 50, 200, 800, or $3200 \mu \mathrm{g}$ of Quil A per head of cattle respectively.

The BHK suspension type vaccines (serotype $O$ and $A$ ) were injected in $5 \mathrm{ml}$ or $10 \mathrm{ml}$ doses with and without the addition of $1000 \mu \mathrm{g}$ of Quil A per head of cattle. The vaccines were injected subcutaneously into 4 animals. Adjuvant activity was estimated by comparison of 2 groups receiving the same dose and serotype, but with or without adjuvant. The significance of the difference was computed using the t-test (Croxton 1959).

\section{Local reaction}

The local tissue reaction at the site of vaccination was investigated by palpation, and an estimate of the swollen area was expressed in $\mathrm{cm}^{2}$. Furthermore the rectal temperature of the animals was followed.

\section{Dose-response experiment}

\section{RESULTS}

Vaccines containing different quantities of Quil A were injected into cattle. The resulting antibody titres assayed with 1 week intervals are listed in Table 1. It appears that peak values were reached after 2 weeks, and the titres then remained constant for the next 2 weeks. By comparison with the group of

T a b l e 1. Assay of the dose-response relationship of Quil A in cattle. A stock vaccine of the Frenkel type was injected into 5 groups of 4 animals. The vaccine was given either alone or in combination with different doses of Quil A.

\begin{tabular}{crrrrr}
\hline & & \multicolumn{4}{c}{ Level of neutralizing antibody after } \\
\cline { 3 - 6 } Group & Quil A & 1 week & 2 weeks & 3 weeks & 4 weeks \\
\hline A & $3200 \mu \mathrm{g}$ & $2^{*}$ & $218^{\star}$ & $221^{\star}$ & $187^{\star}$ \\
$\mathrm{B}$ & $800 \mu \mathrm{g}$ & $1^{\star}$ & $7^{\star}$ & $129^{\star}$ & $103^{\star}$ \\
$\mathrm{C}$ & $200 \mu \mathrm{g}$ & 5 & 24 & 28 & 37 \\
$\mathrm{D}$ & $50 \mu \mathrm{g}$ & 2 & 29 & 32 & 19 \\
$\mathrm{E}$ & $0 \mu \mathrm{g}$ & 2 & 14 & 9 & 12 \\
\hline
\end{tabular}

The reciprocal value of the neutralizing titres $(50 \%$ end point) of cattle sera, arithmetic mean value of 4 animals.

a Dose of Quil A per head of cattle.

* Computed to be significantly different from the corresponding value in group $E$ (vaccine alone). The 0.01 level $(P \leq 0.01)$ was chosen as a criterion of significance. 
cattle receiving no Quil $\mathrm{A}$, it was computed that only the groups receiving $800 \mu \mathrm{g}$ and $3200 \mu \mathrm{g}$, respectively, gave a significantly higher immune response, when the 0.01 level $(P \leq 0.01)$ was chosen as a criterion of significance. It is seen that the antibody titres in these 2 groups on the average were about 10 -fold higher than the control group. In Fig. 1 the antibody titres are plotted as a function of the dose of Quil A. It can be seen that

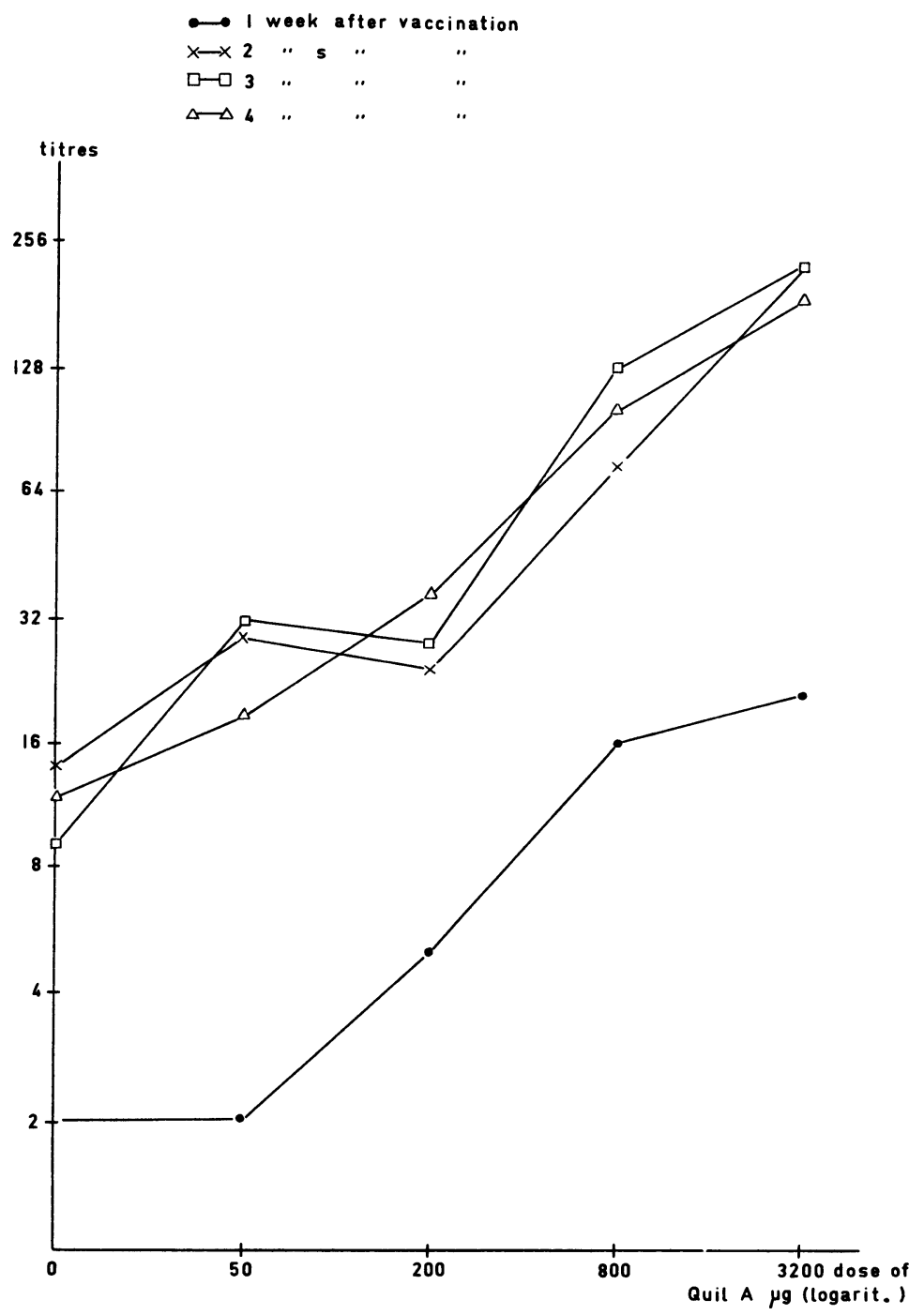

Figure 1. Neutralizing antibody titres of cattle vaccinated with an FMD Frenkel type vaccine. Dose-response relationship of Quil A. 


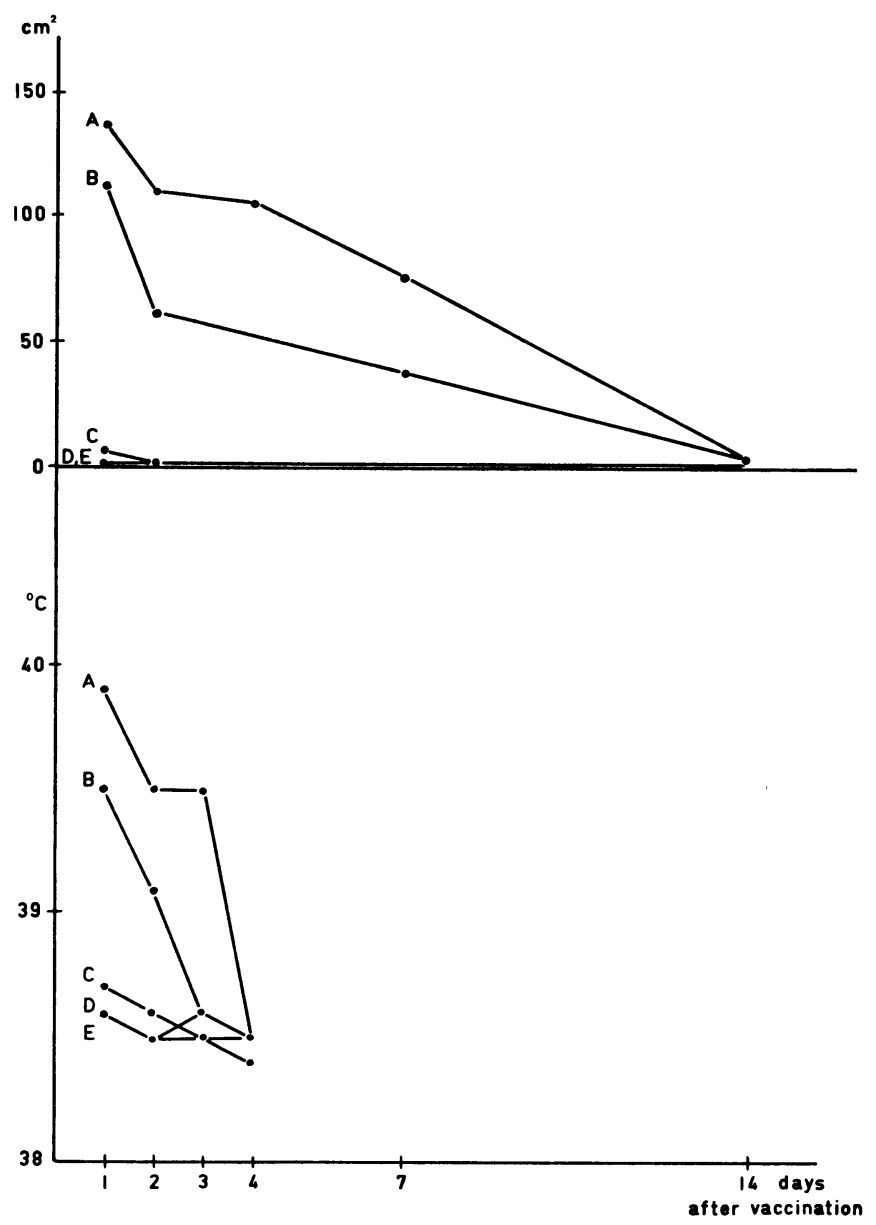

F i g u r e 2. Local reaction and body temperature of cattle vaccinated with an FMD Frenkel type vaccine containing different doses of Quil A. Letters refer to Table 1 .

an S-shaped curve was reached after 1 week only. The doseresponse curves after 2, 3, and 4 weeks, respectively, were all within 1 relatively narrow S-shaped curve.

In Fig. 2 the local inflammatory reaction in $\mathrm{cm}^{2}$, and the rectal temperature of the 5 groups of animals are plotted as a function of time, (arithmetic mean values of 4 animals). It is seen that in the 2 groups of animals ( $A$ and $B$ ) receiving $3200 \mu \mathrm{g}$ and $800 \mu \mathrm{g}$ of Quil A, respectively, a local reaction and a slight increase in body temperature was observed, group A being sig- 
nificantly higher than group $B$. In no case, however, any influence on the general status of the animal, such as willingness to eat, was observed.

From the results of this experiment it appeared that $800 \mu \mathrm{g}$ of Quil A was within the dose range combining high adjuvant activity with a minimum of adverse effects. Consequently, 1000 $\mu \mathrm{g}$ of Quil A per head of cattle was chosen as the therapeutic dose for the subsequent experiments.

\section{Experiments with vaccines of the BHK suspension type}

In the first experiment a vaccine of serotype $O$ was applied. This vaccine was administered in $10 \mathrm{ml}$ and $5 \mathrm{ml}$ doses to 2 groups of 4 cattle (I and II, Table 2). Two groups (III and IV, Table 2) also received $10 \mathrm{ml}$ and $5 \mathrm{ml}$, respectively, of the same vaccine, but with $1 \mathrm{mg}$ of Quil A included. In Table 2 the resulting neutralizing titres are listed. It can be seen that the groups receiving Quil A reached maximum titres after 3 weeks. These 2 titres were almost at the same level and remained constant

T a ble 2. Assay of the adjuvant activity of Quil A in cattle using vaccines of the BHK suspension type.

A vaccine of the BHK suspension type was injected into 8 groups of animals. The vaccine was given either alone or in combination with $1 \mathrm{mg}$ of Quil A per head of cattle.

\begin{tabular}{|c|c|c|c|c|c|c|c|c|c|c|c|}
\hline \multirow[b]{2}{*}{ Group } & \multirow[b]{2}{*}{$\begin{array}{l}\text { Sero- } \\
\text { type }\end{array}$} & \multirow[b]{2}{*}{$\begin{array}{l}\text { Dose of } \\
\text { vaccine }\end{array}$} & \multirow[b]{2}{*}{$\begin{array}{c}\text { Quil A } \\
\text { dose }\end{array}$} & \multicolumn{8}{|c|}{ Level of neutralizing antibody after } \\
\hline & & & & 1 & 2 & 3 & $\begin{array}{l}\text { weeks } \\
4\end{array}$ & $91 / 2$ & $14 \frac{1}{1} 2$ & $19^{1 / 2}$ & $241 / 2$ \\
\hline I & 0 & $10 \mathrm{ml}$ & 0 & 2 & 7 & 7 & 12 & 11 & & & \\
\hline II & $\mathrm{O}$ & $5 \mathrm{ml}$ & 0 & 1 & 3 & 3 & 5 & 5 & & & \\
\hline III & 0 & $10 \mathrm{ml}$ & $1 \mathrm{mg}$ & 5 & $18^{*}$ & $38^{*}$ & $39^{*}$ & $34^{*}$ & & & \\
\hline IV & 0 & $5 \mathrm{ml}$ & $1 \mathrm{mg}$ & 3 & $21^{*}$ & $32^{\star}$ & $32^{\star}$ & $30^{*}$ & & & \\
\hline $\mathrm{V}$ & A & $10 \mathrm{ml}$ & 0 & 1 & 51 & 32 & 21 & 18 & 6 & 5 & 6 \\
\hline VI & $\mathbf{A}$ & $5 \mathrm{ml}$ & 0 & 1 & 13 & 20 & 14 & 13 & & & \\
\hline VII & A & $10 \mathrm{ml}$ & $1 \mathrm{mg}$ & 6 & $419^{*}$ & $239^{\star}$ & $122^{\star}$ & $82^{\star}$ & $38^{*}$ & $32^{\star}$ & $32^{\star}$ \\
\hline VIII & A & $5 \mathrm{ml}$ & $1 \mathrm{mg}$ & 2 & $44^{*}$ & $45 \S$ & $51^{\star}$ & $32^{\star}$ & & & \\
\hline
\end{tabular}

The reciprocal value of the neutralizing titre of cattle sera $1-24 \frac{1}{2}$ weeks after vaccination, arithmetric mean value of 4 animals.

* Computed to be significantly different from the value in the corresponding group receiving no Quil A (III-I, IV-II, VII-V, VIII -VI).

The 0.01 level $(\mathrm{P} \leq 0.01)$ was chosen as a criterion of significance.

$\S$ Significant at the 0.05 level, but not at the 0.01 level. 
for $91 / 2$ weeks, at which time this experiment was terminated. By comparison of group I and III each receiving $10 \mathrm{ml}$ of vaccine, it appeared that Quil $A$ induced about a 4-fold increase in antibody titre. By comparing the $5 \mathrm{ml}$ groups, Quil $A$ induced about a 6-fold increase. The differences were computed to be statistically significant at the 0.01 level.

The second experiment was set up in exactly the same way except that the vaccine was of serotype $A$. This vaccine was of considerably higher potency than the type $O$ vaccine and this characteristic is reflected in the titres listed in Table 2. Two groups (V and VII) receiving $10 \mathrm{ml}$ of vaccine, but without or with Quil A, respectively, were followed during a period of $241 / 2$ weeks. It can be seen that the animals receiving Quil $\mathbf{A}$ together with the vaccine all showed a 3-10-fold increase in antibody titre. The differences were computed to be statistically signifi-

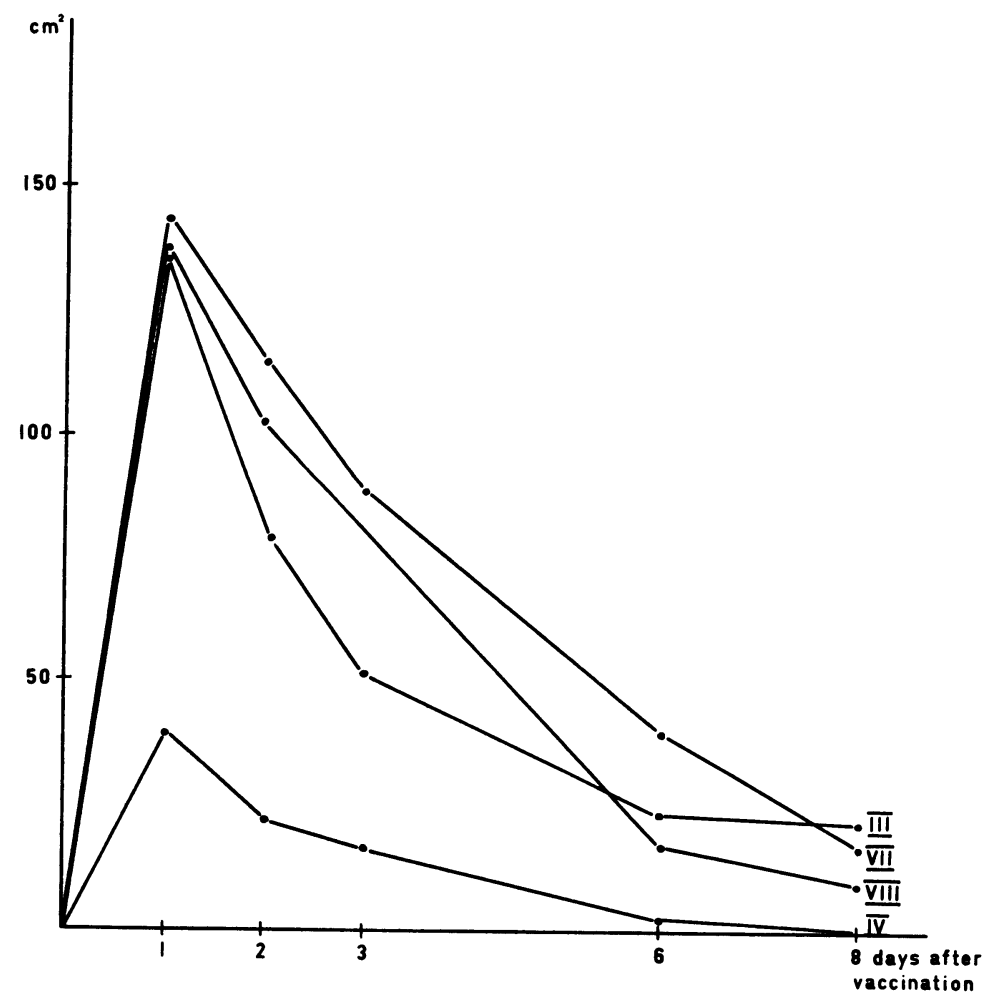

F i g u r e 3. Local reaction of cattle vaccinated with $5 \mathrm{ml}$ and $10 \mathrm{ml}$ doses of an FMD BHK suspension cell type vaccine containing $1 \mathrm{mg}$ of Quil A per dose. Roman numerals refer to Table 2. 
cant at the 0.01 level except in 1 case being significant only at the 0.05 level.

The rectal temperature of the animals in both experiments was followed during the whole period, but no significant increase in body temperature could be observed. In Fig. 3 the local reaction expressed in $\mathbf{c m}^{2}$ is plotted as a function of time (mean values of 4 animals). It can be seen that the local inflammatory reaction is at maximum 1 day after vaccination, and then disappears within 1 week.

\section{DISCUSSION}

The ability of relatively minute quantities $(5-25 \mathrm{mg}$ per dose) of certain saponins to enhance the potency of FMD vaccines (Bayramoglu et al. 1968, Hyslop \& Morrow 1969, Wehmeyer 1969, Charlier et al. 1973), has led to a wide application in commercially available vaccines. Several difficulties attributable to their complex nature, however, are encountered when using these natural compounds (Dalsgaard 1970, Charlier et al.). Standardization of the raw materials or preferably the application of a well defined substance is highly needed.

One of the main drawbacks of the application of saponins has been the rather severe local reaction produced by some of the components when given in doses necessary to enhance the immune response (Charlier et al.). Recent work (Dalsgaard 1972b, 1974, Charlier et al.) has been concerned with the separation of these substances, mainly with the aim to elucidate whether the local irritating effect is inevitably linked to the adjuvant activity. In a previous publication (Dalsgaard 1972a) it was described that a simple dialysis of the substances led to a considerable reduction of the local reactivity. This finding has recently been confirmed by others (Solyom \& Batisz 1974). In a preceding paper (Dalsgaard 1974) the isolation of a virtually pure substance, Quil A, with pronounced adjuvant activity was described, and in this report the experiments were designed to evaluate at which dose levels this substance may be applied to cattle, the aim being to combine maximum adjuvant activity with a minimum of local reaction.

In the dose-response experiment Quil A was added to a stock vaccine containing aluminium hydroxide. It could be argued that a more accurate estimate of the adjuvant activity might have 
been obtained if Quil $A$ had been combined with antigen alone. But, since aluminium hydroxide in the FMD vaccine is not only acting as an adjuvant but also as a carrier substance conferring stability upon virus during storage of vaccines, it was felt that this constituent of the classical FMD vaccine could hardly be omitted. From this follows that Quil A not necessarily has to be combined with aluminum hydroxide. In previous experiments in guinea pigs (Dalsgaard 1972a, 1974) it was shown that Quil A possesses a pronounced adjuvant activity combined with the antigen in aqueous medium, and a recent report (Mowat 1974) has provided evidence for the adjuvant activity in aqueous medium of a commercially available crude saponin preparation (Saponin P 3, Food Industries, Cheshire, England). In this crude saponin Quil $\mathrm{A}$ is present in an amount corresponding to $20 \%$ of the constituents as estimated by analysis of a sample at our disposal (unpublished results), and previous experiences indicate that Quil $A$ is the major active substance (Dalsgaard 1970).

From the dose-response results of the present paper it can be seen that Quil $\mathrm{A}$ has highly significant adjuvant activity in the system tested at dose levels above $800 \mu \mathrm{g}$ per head of cattle. Three weeks after vaccination the difference in antibody titre between $800 \mu \mathrm{g}$ and $3200 \mu \mathrm{g}$ is not significant, but the local reaction and the influence on body temperature is more pronounced with $3200 \mu \mathrm{g}$. From the dose-response curve (Fig. 1) it was concluded that $1 \mathrm{mg}$ of Quil A constituted a practical dose for therapeutical use.

This dose of Quil A was tested in the vaccination of cattle with vaccines of the BHK suspension type. These vaccine types are attractive due to their quick availability in large volumes and because of their low cost compared to other methods of virus propagation. Due to these characteristics, the BHK suspension type vaccines are expected to form the basis of future control of FMD. Especially in the developing countries, where a cheap vaccine and a low dose is of major importance. The application of a potent and reliable adjuvant is therefore of special importance in vaccines of the BHK suspension type. The 2 vaccines used in the present experiment were of different antigenic potency. The type $O$ vaccine was of low potency, only producing a maximum neutralizing titre of 12 , whereas the type $A$ vaccine produced a maximum titre of 51 when given alone in a $10 \mathrm{ml}$ dose. Ten $\mathrm{ml}$ is the recommended FMD vaccine (non-concen- 
trated) dose for cattle in Denmark. From the results it can be seen that the addition of $1 \mathrm{mg}$ of Quil $A$ to the vaccines produced a highly significant increase in the production of neutralizing antibodies. In no case even by halving the vaccine dose to $5 \mathrm{ml}$ was the maximum titre below 32. In 1 group of animals producing the highest antibody response the titre was followed during a period of almost half a year. When compared to the control group (Table 1) the titres of group VII remained about 6 times as high during the whole period. The local reactions induced by Quil $A$ in these experiments is considered to be at an acceptable level, and it is by far lower than the reactions reported for crude saponin preparations (Bayramoglu et al. 1968, Charlier et al.). The local reaction of Quil $A$ is considered to be due to the hemolytical properties of the substance (Dalsgaard 1974), but in crude saponin preparations other mechanisms may be involved. In a subsequent report evidence is presented that some of the contaminants of non-purified saponin adjuvants have serum precipitating properties. Quil A does not show this effect, nor does it induce precipitating antibodies in rabbits. It is concluded that Quil $A$ is a valuable adjuvant for use in the induction of neutralizing antibodies against FMD in cattle.

\section{REFERENCES}

Anderson, E. C., R. C. Masters \& G. N. Mowat: Immune response of pigs to inactivated foot-and-mouth disease vaccines. Res. vet. Sci. 1971, 12, 351-357.

Bayramoglu, O., N. Unluleblebici \& H. C. Girard: Durée de l'immunité consécutive a l'utilisation du vaccin antiaphteux préparé avec 10 et 25 milligrammes de saponine par dose. (Duration of the immunity after application of a foot-and-mouth disease vaccine prepared with 10 or $25 \mathrm{mg}$ of saponin per dose). Bull. Acad. vét. Fr. 1968, 41, 165-168.

Charlier, G., R. Strobbe, J. Debecq \& J. Leunen: Studies about the adjuvant activity of saponin fractions in foot-and-mouth disease vaccines. Arch. exp. Vet.-Med. 1973, 27, 783-789.

Croxton, F. E.: Elementary Statistics, with Applications in Medicine and the Biological Sciences. Dover Publications Inc. New York 1959.

Dalsgaard, K.: Thin-layer chromatographic fingerprinting of commercially available saponins. Dansk T. Farm. 1970, 44, 327-331.

Dalsgaard, K.: Saponin adjuvants. I. The presence of a non-dialysable fraction of Quillaja saponaria Molina with adjuvant activity in foot-and-mouth disease vaccines. Bull. Off. int. Epiz. 1972a, 77, $1289-1295$. 
Dalsgaard, K.: Saponin adjuvants. II. The influence of dialysis of saponin on the local irritating effect. Bull. Off. int. Epiz. 1972b, 77, 1297-1301.

Dalsgaard, K.: Saponin adjuvants. III. Isolation of a substance from Quillaja saponaria Molina with adjuvant activity in foot-andmouth disease vaccines. Arch. ges. Virusforsch. 1974, 44, 243254.

Espinet, R. G.: Nouveau vaccin antiaphteux a complexe glucoviral. (A new foot-and-mouth disease vaccine with a glycoviral complex). Gac. vet. (B. Aires) 1951, 13, $268-272$.

Frenkel, $H$. S.: Research on foot-and-mouth disease. II. The cultivation of the virus in explantations of tongue epithelium of bovine animals. Amer. J. vet. Res. 1950, 11, 371-380.

Hyslop, N. St. G. \& A. W. Morrow: The influence of aluminium hydroxide content, dose volume and the inclusion of saponin on the efficacy of inactivated foot-and-mouth disease vaccines. Res. vet. Sci. 1969, 10, 109-120.

Kärber, G.: Beitrag zur kollektiven Behandlung pharmakologischer Reihenversuche. (Contribution to the treatment of pharmacological data). Naunyn-Schmiedeberg's Arch. exp. Path. Pharmak. 1931, 162, 480-483.

Mowat, G. N.: A comparison of the adjuvant effect of saponin and oil emulsions in foot-and-mouth disease vaccines for cattle. Bull. Off. int. Epiz. 1974, 81, 1319-1330.

Solyom, F. \& L. Batisz: The biological properties of saponin and its value as vaccine adjuvant. Bull. Off. int. Epiz. 1974, 81, 10671074.

Wehmeyer, $P .:$ The influence of saponins on the immunizing property of foot-and-mouth disease vaccines of varying ages. Nord. Vet.Med. 1969, 21, 92-96.

\section{SAMMENDRAG}

Saponin adjuvanter. VI. En vurdering af adjuvanten Quil A ved vaccination af kvæg mod mund-og klovesyge.

Saponin adjuvanten Quil A blev undersøgt i vaccination af kvæg mod mund- og klovesyge.

Der etableredes en dosis-virkningskurve af Quil A's indflydelse på de neutraliserende antistoffer $i$ serum $i$ forbindelse med vaccination med en Frenkel vaccine.

Ti ml vaccine blev blandet med 0, 50, 200, 800 eller $3200 \mu \mathrm{g}$ Quil A. Hver blanding blev injiceret i 4 dyr.

Den lokale reaktion på injektionsstedet blev unders $\varnothing \mathrm{gt}$ efter injektion af vaccinen alene og vaccinen tilsat Quil A. Stigende mængder af Quil A øgede den lokale reaktion på injektionsstedet.

På dette grundlag ansloges en dosis på $1 \mathrm{mg}$ Quil $\mathrm{A}$ at kombinere maximal adjuvant aktivitet med et minimum af bivirkninger. Denne 
dosis blev unders $\varnothing$ gt $\mathrm{i}$ vaccination af kvæg med en mund- og klovesyge vaccine baseret på BHK suspensionscellevirus, af henholdsvis type $O$ og A. Vaccinen blev afprøvet i 10 og $5 \mathrm{ml}$ doser med eller uden Quil A. Hver kombination blev givet til 4 dyr.

Det konkluderedes at Quil A er en værdifuld adjuvant ved dannelsen af neutraliserende antistoffer mod mund- og klovesyge i kvæg.

(Received April 28, 1977).

Reprints may be requested from: K. Dalsgaard, the State Veterinary Institute for Virus Research, Lindholm, DK-4771 Kalvehave, Denmark. 